\title{
Electrospray Ionization Mass Spectrometry of Phosphopeptides Isolated by On-Line Immobilized Metal-Ion Affinity Chromatography
}

\author{
Lydia M. Nuwaysir and John T. Stults \\ Protein Chemistry Department, Genentech, Inc., Snuth San Francisco, California, USA
}

\begin{abstract}
Electrospray ionization mass spectrometry (ESI/MS) affords a rapid and sensitive technique for determining peptides produced by the enzymatic digestion of phosphoproteins. When coupled with on-line immobilized metal-ion affinity chromatography (IMAC), the combination allows separation and mass spectrometric identification of phosphorylated and nonphosphorylated peptides. In this study, the feasibility and general applicability of on-line IMAC/ESI/MS is investigated by using immobilized ferric ions for selective chelation of several phosphotyrosine and phosphoserine peptides. The sensitivity and practicality of the technique for phosphoproteins are demonstrated via the analysis of $30 \mathrm{pmol}(\sim 0.7 \mu \mathrm{g})$ of bovine $\beta$-casein purified by sodium dodecylsulfate-polyacrylamide gel electrophoresis, electroblotted onto a polyvinylidene difluoride membrane, and digested in situ with trypsin. It is observed that on-line IMAC/ESI/MS suffers less from sample losses than experiments performed off-line, suggesting that the limiting factors in sensitivity for this technique are the purification procedures and sample handling rather than the IMAC and mass spectrometry. Thus, the ability to inject the tryptic digest of an electroblotted protein directly onto the column without buffer exchange and to analyze the eluent directly via on-line coupling of the IMAC column to the mass spectrometer greatly reduces sample losses incurred through sample handling and provides a convenient method for analyzing phosphopeptides at low levels. ( $(\mathrm{Am}$ Soc Mass Spectrom 1993, 4, 662-669)
\end{abstract}

$\mathrm{P}$ rotein phosphorylation/dephosphorylation plays a major role in the regulation of a wide variety of metabolic pathways and intracellular functions [1-3]. To understand more about the function of protein phosphorylation, it is necessary to identify the specific amino acid residues that become phosphorylated. The most common type of phosphorylation encountered, in terms of both extent of distribution of phosphoproteins within cells and quantity [4], is $O^{-}$ linked, involving the amino acids serine, threonine, and tyrosine.

Analytical methods that have been used to detect and/or characterize phosphorylation sites typically involve radiolabeling proteins with $\left[{ }^{32} \mathrm{P}\right]$ adenosine triphosphate (ATP), either in vivo or in vitro [5]. Besides the obvious precautions when working with radioactivity, one must be certain that complete incorporation of ${ }^{32} \mathrm{P}$ has taken place and that an equilibrium has been established within the cell. Allowances must be made for endogenous (nonradiolabeled) ATP that may still be present. Moreover, some proteins may be

Address reprint requests to John T. Stults, Genentech, Inc., 460 Point San Bruno boulevard, Mail Stop 63, South San Francisco, CA 94080. phosphorylated at the time of labeling, and thus the incorporation of ${ }^{32} \mathrm{P}$ may depend on the activity of phosphatases to remove bound nonradioactive phosphate. In addition, artifactual phosphorylation may occur owing to denaturation of the protein, exposing other potential phosphorylatable sites that in vivo would not be accessible. Despite these concerns, ${ }^{32} \mathrm{P}$ labeling is widely used because of the high sensitivity of assays based on radioactivity.

Once a protein has been radiolabeled, it is usually chemically or enzymatically cleaved into smaller peptides for further analysis. Amino-terminal sequencing by Edman degradation [6-8] is commonly used to identify specific phosphorylated residues. Edman degradation does not necessarily require a radioactive label; however, without radiolabeling to identify phosphopeptides, substantial time is required to sequence all potentially phosphorylated peptides within a protein.

Mass spectrometric methods for identifying and characterizing nonradiolabeled phosphopeptides are inherently faster because the masses of many peptides can be determined quickly, and phosphopeptides are identified by a mass increase ( +80 Da per phosphate) [9-17]. The specific phosphorylated residue(s) in a 
peptide are most often determined by tandem mass spectrometry (MS/MS). Most of the results to date have been based on fast-atom bombardment (FAB) [10-14]. Electrospray ionization (ESI) [15, 16] has some advantages over FAB for phosphopeptide analysis. The mass range of ESI is substantially higher, and detection limits, under carefully controlled conditions, can be in the subpicomole range. ESI can be easily interfaced for on-line high-performance liquid chromatographic (HPLC) separation (FAB can also be interfaced with HPLC via continuous-flow FAB). The utility of ESI for phosphopeptide analysis was demonstrated by Palczewski et al. [18] in the study of Rhodopsin kinase, in which ${ }^{32}$ P-labeling was used to identify the phosphorylated peptides.

The analysis of large phosphoproteins by mass spectrometry is a particular challenge, primarily because of the large number of peptides that have to be analyzed. Simultaneous ionization of all peptides in a complex mixture is rarely if ever achieved without prior chromatographic separation. Even then, incomplete separation of many components, a common occurrence, makes data analysis difficult. Moreover, not all expected peptides are always identified, and often partial clips or nonspecific chemical or enzymatic cleavages are encountered, such as occasional chymotryptic clips observed with the enzyme trypsin.

Therefore, a method to identify specifically phosphopeptides would be valuable. Covey et al. [16] have shown that neutral-loss scans can identify doubly charged ions of phosphoserine-containing peptides. An alternative is the specific isolation of phosphopeptides from a mixture. Immobilized metal-ion affinity chromatography (IMAC) has been shown to be useful for this purpose [19-22]. Immohilized $\mathrm{Fe}^{3+}$ ions selectively retain phosphorylated proteins and peptides. This technique has been used successfully off-line by Michel et al. [14] prior to FAB mass spectrometry analysis. For analysis of low amounts of material, however, on-line methods are preferable because sample handling can be minimized.

In this study, we describe the development of on-line micro-IMAC/ESI mass spectrometry (IMAC/ESI/MS) for the analysis of low levels ( $<30$ pmol) of phosphopeptides. Following this, we describe a generally useful method to deal with large proteins of poor solubility and low availability. Proteins that are purified by sodium dodecylsulfate-polyacrylamide gel electrophoresis (SDS-PAGE) are transferred by electroblotting onto a suitable membrane that fixes the protein in an environment virtually free of interfering buffer components. The analysis utilizes in situ enzymatic digestion of proteins on membranes, followed by phosphopeptide isolation with micro-IMAC columns, either on-line with ESI/MS or off-line for subsequent analysis by matrix-assisted laser desorption ionization mass spectrometry (MALDI/MS). This method is demonstrated for $\beta$-casein, a readily available phosphoprotein of $24 \mathrm{kDa}$, containing five phosphoscrine residues.

\section{Experimental}

\section{Chemicals}

$\beta$-Casein, kemptide, protein kinase catalytic subunit, $\alpha-L(-)$ fucose, ATP, ammonium acetate, polyvinylpyrrolidone (average MW 40,000) (PVP-40), and 3-cyclohexylamino 1-propanesulfonic acid (CAPS) were purchased from Sigma Chemical Co. (St. Louis, MO). Acetic acid was purchased from Fisher Chemical (Fair Lawn, NJ). Acetonitrile was purchased from JT Baker, Inc. (Phillipsburg, NJ). Ammonium hydroxide, $N$-ethylmorpholine, ferric chloride hexahydrate, and 2,5-dihydroxybenzoic acid were purchased from Aldrich Chemical Co. (Milwaukee, WI). Chloroform and $\mathrm{HCl}$ were purchased from Mallinckrodt (Paris, KY). Dithiothreitol (DTT) was purchased from Boehringer Mannheim Corp. (Indianapolis, IN). Methanol was purchased from B-J Baxter (Muskegon, MI). Trypsin was purchased from Promega Corp. (Madison, WI). SDS sample buffer, Mark12 molecular weight standards, and 4-20\% Tris-glycine gels were purchased from Novex (San Diego, CA). Phosphotyrosine peptides were a gift from Dr. Geoff Tregear of the Florey Institute, Melbourne, Australia.

\section{SDS-PAGE, Electroblotting, and Tryptic Digestion}

Gel electrophoresis was performed using a Novex (San Diego, CA) Xcell Mini-cell and Novex precast 4-20\% gradient Tris-glycine gels, 15 wells, $1.0 \mathrm{~mm}$ thick. Gel electrophoresis is commonly used as a purification step in preparing biological samples and allows separation of a protein of interest from other protein impurities and buffer components. Electroblotting was performed using a BioRad Mini two-dimensional Trans-blot cell. Electroblotting transfers the protein from the gel to a membrane under the influence of an electric field. It serves to remove SDS from the protein (acquired during the electrophoresis) and fix the protein from the gel onto an inert support for further manipulation and study. ProBlott (Applied Biosystems, Foster City, $C A)$ polyvinylidene difluoride (PVDF) membranes were used for electroblotting proteins in a solution of $10 \mathrm{mM}$ CAPS, $\mathrm{pH} 11$, and $20 \%$ methanol for $1 \mathrm{~h}$ at $250 \mathrm{~mA}$ constant current. Membrancs were stained for $1 \mathrm{~min}$ with ProBlott stain to visualize the proteins $(0.1 \%$ Coomassie Brilliant Blue, $1 \%$ acetic acid, and $40 \%$ methanol), destained for 3 min by using $10 \%$ acetic acid in $50 \%$ methanol, and then thoroughly washed with distilled water and allowed to dry.

In situ reduction, alkylation, and tryptic digestion have been discussed previously in detail by Henzel and co-workers [23, 24]. Protein bands were cut from the PVDF membrane, taking care to cut closely around each band so as to include as little excess PVDF membrane as possible. The excised bands were transferred to microcentrifuge tubes, and the residual stain and 
SDS were removed by a modified chloroform/ methanol precipitation as follows: the membranes were wetted with $1 \mu \mathrm{L}$ of methanol; then $100 \mu \mathrm{L}$ of distilled water was added followed by $400 \mu \mathrm{L}$ of methanol. The mixture was vortexed for $1 \mathrm{~min}$; then $100 \mu \mathrm{L}$ of chloroform was added, and the mixture was vortexed again prior to solvent removal. For proteins that contain disulfide bonds, the protein is reduced and alkylated prior to tryptic digestion to denature the protein, thus ensuring that the enzyme will be able to interact efficiently with the protein on the membrane. Specifically, the reduction/alkylation reactions will reduce disulfide bonds between cysteine residues and alkylate the resulting free sulfhydryl groups to form carboxymethylcysteines. In-situ reduction is performed as follows: $100 \mu \mathrm{L}$ of reduction buffer $(5 \mathrm{mM}$ ethylenediaminetetraacetic acid, $7 \mathrm{mM}$ DTT, and $0.5 \mathrm{M}$ Tris- $\mathrm{HCl}, \mathrm{pH}$ 8.5 in $10 \%$ acetonitrile) is added to the membrane and allowed to incubate for $1 \mathrm{~h}$ at $45^{\circ} \mathrm{C}$. The mixture is allowed to cool to room temperature, and $10 \mu \mathrm{L}$ of alkylation buffer $(0.5 \mathrm{M} \mathrm{NaOH}, 200 \mathrm{mM}$ iodoacetic acid) is added to the membrane still in the reduction buffer. This mixture is then allowed to incubate at room temperature for $20 \mathrm{~min}$ in the dark. $\beta$-Casein does not contain any cysteine residues, and therefore this portion of the procedure was amitted for most of the experiments.

For digestion, the membranes were washed three times with $10 \%$ acetonitrile (to remove residual alkylation/reduction buffer) and then vortexed for $20 \mathrm{~min}$ in a solution of $0.2 \%$ PVP- $400.1 \%$ acetic acid. The PVP-40 surfactant prevents protease adsorption to the membrane. The PVP-40 solution was removed, and the membranes were washed twice with $10 \%$ acetonitrile, followed by one wash of $20 \%$ acetonitrile and one wash of $0.1 \mathrm{M} \mathrm{N}$-ethylmorpholine in $10 \%$ acetonitrile to remove any residual PVP-40 solution. Membranes were then digested in $50 \mu \mathrm{L}$ of digest buffer $(0.1 \mathrm{M}$ N-ethylmorpholine, $10 \%$ acetonitrile, $0.2 \mu \mathrm{g}$ of Promega modified trypsin) and incubated for $12 \mathrm{~h}$ at $37{ }^{\circ} \mathrm{C}$. A second aliquot of trypsin was added, and incubation continued for an additional $12 \mathrm{~h}$ at $37^{\circ} \mathrm{C}$. The digestion was halted by injecting the solution onto the IMAC column.

Solution digestion of $\beta$-casein was either performed in $0.1 \mathrm{M} \mathrm{N}$-ethylmorpholine or $0.1 \mathrm{M} \mathrm{NH}_{4} \mathrm{HCO}_{3}$ by using an enzyme/substrate ratio of $1: 100(\mathrm{w} / \mathrm{w})$. The digestion was carried out for $24 \mathrm{~h}$ at $37{ }^{\circ} \mathrm{C}$, with a second aliquot of trypsin added after $12 \mathrm{~h}$. The digestion was halted by drying the sample or injecting the solution onto the IMAC column.

\section{Kemptide Phosphorylation}

Phosphorylation of $5 \mathrm{mg}$ of kemptide [7] was carried out in $1.25 \mathrm{~mL} 50 \mathrm{mM} \mathrm{K}_{2} \mathrm{HPO}_{4}, 18 \mathrm{mM} \mathrm{MgCl}_{2}$, and 10 $\mathrm{mM}$ ATP adjusted to $\mathrm{pH} 6.8$ with $\mathrm{HCl}$. Protein kinase catalytic subunit ( $500 \mathrm{U}$ in $160 \mu \mathrm{L}$ of $6 \mathrm{mg} / \mathrm{mL}$ DTT) was added to the kemptide solution, and the reaction was incubated at $37^{\circ} \mathrm{C}$ for $3 \mathrm{~h}$.

\section{IMAC}

IMAC was accomplished as follows: $\Lambda 1 \mathrm{~mm}$ i.d. $x$ $1.59-\mathrm{mm}$ o.d. $\times 10-\mathrm{cm}$-long piece of Teflon tubing was filled with a $20 \%$ ethanol slurry of chelating Sepharose Fast Flow (Pharmacia, LKB Biotechnology, Piscataway, NJ). The column was assembled by using standard low-pressure flangeless fittings available from Upchurch Scientific, Inc. (Oak Harbor, WA). One end of the tubing was connected to a union containing a piece of 5-mm-diameter Durapore membrane filter cut to fit against the inside wall of the union (low-proteinbinding PVDF membrane) (Millipore Corporation, Bedford, MA). This filter acted as a physical support to hold in the Sepharose. The other side of this union was connected through a fused silica capillary to the mass spectrometer. One milliliter of a $20 \%$ ethanol solution, followed by $1 \mathrm{~mL}$ of distilled $\mathrm{H}_{2} \mathrm{O}$ was pumped through the column with a Harvard Apparatus (South Natick, MA) syringe pump at a flow rate between 200 and $500 \mu \mathrm{L} / \mathrm{min}$. These high flow rates served to compact the Sepharose against the PVDF membrane to give a final length of stationary phase within the Teflon tubing of approximately $6 \mathrm{~cm}$ (resulting in a column bed volume of approximately $50 \mu \mathrm{L}$ ). No frit on the front of the column was needed as long as flow was only allowed in the forward direction against the PVDF membrane. The column was activated with metal ions by pumping $200 \mu \mathrm{L}$ of $30 \mathrm{mM} \mathrm{FeCl}_{3}$ solution at 50 $\mu \mathrm{L} / \mathrm{min}$ through the column. The excess metal was washed with $2 \mathrm{~mL}$ of $\mathrm{H}_{2} \mathrm{O}$ and equilibrated with $1 \mathrm{~mL}$ of buffer A (sce below). Prior to initial use, two blank runs of all buffers were passed through the column.

Samples were either loaded directly onto the column in acidified (to $\mathrm{pH} 3.5$ with acetic acid) digest buffer solutions or in $0.1 \mathrm{M}$ acetic acid. Loading the proteolytic digest solution directly onto the IMAC column minimizes sample handling. We found that $N$ ethylmorpholine, because it is a tertiary amine, is compatible with the IMAC column such that the digest can be directly injected onto the column without buffer exchange. More common buffers such as Tris- $\mathrm{HCl}$ or $\mathrm{NH}_{4} \mathrm{HCO}_{3}$, contain primary or secondary amines and compete with the phosphopeptides for chelation with $\mathrm{Fe}^{3+}$ during the load procedure [25]. Best results were obtained when sample load volumes were less than the total volume of the column $(<50 \mu \mathrm{L})$. After the column was loaded, the column was connected through the end union to the ESI source via a $50-\mathrm{cm}$ length of $70-\mu \mathrm{m}$ i.d. $\times 150-\mu \mathrm{m}$ o.d. fused silica capillary transfer line. The following buffers were used as eluents to develop the column:

Buffer A: $\quad 0.1 \mathrm{M}$ acetic acid.

Buffer B: Milli-Q distilled water.

Buffer C: $0.1 \%(\mathrm{w} / \mathrm{v})$ ammonium acetate adjusted to $\mathrm{pH} 8.0$ with $10 \%$ ammonium hydroxide.

Buffer D: $\quad 0.1 \%(\mathrm{w} / \mathrm{v})$ ammonium acetate adjusted to $\mathrm{pH} 9.5$ with $10 \%$ ammonium hydroxide. 
Buffer $E: 2 \%$ acetonitrile, $0.1 \%(\mathrm{w} / \mathrm{v})$ ammonium acetate adjusted to $\mathrm{pH} 10.5$ with $10 \%$ ammonium hydroxide.

Following sample loading, $300 \mu \mathrm{L}$ of buffer $\mathrm{A}$ was passed through the column at $10 \mu \mathrm{L} / \mathrm{min}$. Mass spectral data collected during this wash allowed identification of nonphosphorylated peptides that do not chelate with the immobilized $\mathrm{Fe}^{31}$ ions. Following buffer A, $200 \mu \mathrm{L}$ of buffer B and $200 \mu \mathrm{L}$ of buffer $\mathrm{C}$ were passed through the column at a flow rate of 20 $\mu \mathrm{L} / \mathrm{min}$. Phosphopeptides were eluted from the column and into the mass spectrometer with $300 \mu \mathrm{L}$ of buffer $\mathrm{D}$ at a flow rate of $5 \mu \mathrm{L} / \mathrm{min}$. Alternatively, buffers $C$ and D were replaced with $300 \mu \mathrm{L}$ of buffer $\mathrm{E}$ to elute the phosphopeptides.

\section{Mass Spectrometry}

Experiments were performed by using a SCIEX (Thornhill, Ontario, Canada) API III triple quadrupole mass spectrometer equipped with a pneumatically assisted ESI source (ion spray). Each scan was acquired over the range $m / z 400-2200$ by using a step of $0.5 \mathrm{u}$, a dwell time of $1.5 \mathrm{~ms}$, a mass defect of $50 \mu \mathrm{u}$, and an $80-\mathrm{V}$ orifice potential. All on-line IMAC/ESI mass spectra were background subtracted. The background IMAC spectrum contains buffer ions and ions resulting from column degradation.

A Vestec LaserTec ResearcH time-of-flight mass spectrometer (Vestec Corp., Houston, TX) was used for MALDI experiments. Dried samples were dissolved in $2 \mu \mathrm{L}$ of $0.1 \mathrm{M}$ acetic acid, to which was added $2 \mu \mathrm{L}$ of dihydroxybenzoic acid solution [saturated in $2 \%$ acetonitrile, $0.1 \%$ trifluoroacetic acid (TFA)] $+2 \mu \mathrm{L}$ of $\alpha-\mathrm{L}(-)$ fucose solution ( $50 \mathrm{mM}, 0.1 \%$ TFA). We found that this carbohydrate-containing matrix [26] gave superior results for tryptic digests [27]. The resulting mixture was then applied to a stainless steel probe tip, and the solvent was allowed to evaporate. Samples were irradiated with an LSI VSL-337ND (Laser Science, Inc., Cambridge, MA) nitrogen laser, and spectra were generated from 32 consecutive laser shots. Ions were accelerated to $30 \mathrm{kV}$ prior to detection, and 5-ns time bins were used for recording signal transients.

\section{Results and Discussion}

The viability of on-line micro-IMAC for low levels of both aryl- and alkyl-linked $O$-phosphorylated amino acids was examined by experiments with synthetic peptides containing phosphotyrosine or phosphoserine. Phosphothreonine-containing peptides are known to behave very similarly to peptides containing phosphoserine [4, 19, 21], and, thus, were not included in this study. Figure 1a displays the mass spectrum obtained from a mixture of three synthetic phosphotyro- sine peptides, 10 pmol each of peptides I, II, and III (Table 1), as they eluted together from the IMAC column. As shown in the total ion current chromatogram (Figure 1a, inset), the elution profile of these peptides is fairly sharp, indicating that the majority of the phosphopeptides elute within a fairly small volume, approximately $15 \mu \mathrm{L}$. Singly charged molecular ions are observed for peptide I ( $\mathrm{m} / \mathrm{z}$ 704.4), whereas doubly charged molecular ions are formed for peptides II and III ( $m / z 563.8$ and 794.4, respectively), as well as the triply charged ions ( $m / z$ 458.2) for peptide III. The IMAC/ESI mass spectral data obtained from 20 pmol of the phosphoserine peptide IV, kemptide, is shown in Figure 1b. All of the kemptide that underwent phosphorylation during the enzymatic reaction becomes chelated to the immobilized $\mathrm{Fe}^{3+}$ ions and elutes in the buffer D wash. As was the case with the phosphotyrosine peptides, the elution profile of phosphokemptide appears quite sharp, and the compound elutes within $6 \mu \mathrm{L}$ of buffer (Figure $1 \mathrm{~b}$, inset).

The application of the IMAC isolation method to a more complex mixture of peptides was studied by using a tryptic digest of the phosphoprotein $\beta$-casein. This digest yields 16 different peptides, two of which contain phosphoserine residues-the quadruply phosphorylated T1-2(4P) and the singly phosphorylated T6(1P) -as is shown in Table 1. Data from the infusion of $4 \mu \mathrm{L}$ of a $5-\mathrm{pmol} / \mu \mathrm{L}$ solution of the mixture of tryptic peptides are shown in Figure 2. Virtually all of the peptides are identified, including the T1-2(4P) and T6(1P) peptides. The data are sufficient for analysis of a well-characterized sample, such as $\beta$-casein, in which the complete sequence is known and phosphorylated residues have previously been identified [28-31].

For proteins with unknown phosphorylated residues, however, the complexity of the spectrum warrants separation of the peptide mixture prior to mass spectral analysis. The most common separation technique, reversed-phase HPLC, has been used extensively for the on-line separation of proteolytic digests. On-line injection of a $\beta$-casein tryptic digest onto a reversed-phase $C 18$ HPLC column results in excellent separation for most of the tryptic peptides. As has been noted in many literature reports with regard to the HPLC of casein protein digests, however, the highly phosphorylated peptides, such as the T1-2(4P) of $\boldsymbol{\beta}$ casein, were detected in very low abundance or not at all $[13,28,29,32]$. We observed the same phenomena, as is depicted in Figure 3: the total ion current (TIC) trace for the LC mass spectra of 60 pmol of $\beta$-casein tryptic digest. In this case, virtually every tryptic peptide between molecular weight (MW) 400 and 2200 (the mass range utilized for this particular experiment) is identified, including the singly phosphorylated T6(1P), as well as several nontryptic and modified peptides. Several smaller peptides ( $<400 \mathrm{Da}$ ) and the quadruply phosphorylated $\mathrm{T} 1-2(4 \mathrm{P})$ peptide are not observed. Under the acidic conditions normally used for reversed-phase HPLC, the peptide may be too hydrophobic for high recovery. Another potential 
Table 1. Peptide sequences

\begin{tabular}{|c|c|c|c|c|}
\hline Label & \multicolumn{2}{|c|}{ Molecular Weight } & \multicolumn{2}{|r|}{ Sequence $^{a}$} \\
\hline \multicolumn{5}{|c|}{ Phosphorylated peptides } \\
\hline I & \multicolumn{2}{|c|}{703.65} & \multicolumn{2}{|c|}{$\begin{array}{l}\text { GVPYAASG (fragment of viral protein } p^{85 \text { gag-fes }} \text { ) } \\
\text { site of epidermal growth factor receptor kinase) }\end{array}$} \\
\hline II & \multicolumn{2}{|c|}{1126.18} & \multicolumn{2}{|c|}{ DRVPYTHPF (human angiotensin II) } \\
\hline III & \multicolumn{2}{|c|}{1586.71} & \multicolumn{2}{|c|}{$\begin{array}{l}\text { TFLPVPEPYINQSV (primary autophosphorylation site } \\
\text { of epithelial growth factor receptor kinase) }\end{array}$} \\
\hline IV & \multicolumn{2}{|c|}{851.91} & \multicolumn{2}{|c|}{$\begin{array}{l}\text { LRRApSLG (kemptide; a heptapeptide substrate } \\
\text { for cyclic adenosine monophosphate dependent } \\
\text { protein kinases) }\end{array}$} \\
\hline Label & From & To & Molecular Weight & Sequence \\
\hline \multicolumn{5}{|c|}{$\beta$-casein tryptic peptides } \\
\hline $11-2(4 \mathrm{P})$ & 1 & 25 & 3122.45 & KELEELNVPGEIVEPSLPSPSpSEESIIK \\
\hline $\mathrm{T} 3$ & 26 & 28 & 373.45 & INK \\
\hline $\mathrm{T} 4$ & 29 & 29 & 146.19 & $\mathbf{K}$ \\
\hline T5 & 30 & 32 & 388.46 & IEK \\
\hline T6(1P) & 33 & 48 & 2061.98 & FQPSEEQQQTEDELQDK \\
\hline $\mathrm{T} 7 \mathrm{a}$ & 49 & 68 & 2223.56 & IHPFAQTQSLVYPFIPGPIPN \\
\hline $\mathrm{T} 7 \mathrm{~b}$ & 69 & 97 & 3113.71 & SLPQNIPPLTQTPVVVPPFLQPEVMGVSK \\
\hline T7 & & & 5319.25 & \\
\hline T8 & 98 & 99 & 245.32 & VK \\
\hline T9 & 100 & 105 & 645.77 & EAMAPK \\
\hline T10 & 106 & 107 & 283.33 & HK \\
\hline T11 & 108 & 113 & 747.91 & EMPFPK \\
\hline $\mathrm{T} 12$ & 114 & 169 & 6361.34 & YPVQPFTESQSLTLTDVENLHLPPLLLQ \\
\hline & & & & SWMHQPHQPLPPTVMFPPQSVLSLSQSK \\
\hline T13 & 170 & 176 & 780.96 & VLPVPEK \\
\hline T14 & 177 & 183 & 829.95 & AVPYPQR \\
\hline T15 & 184 & 202 & 2185.61 & DMPIQAFLLYQQPVLGPVR \\
\hline T16 & 203 & 209 & 741.93 & GPFPIIV \\
\hline
\end{tabular}

${ }^{\text {a }}$ Phosphorylated residues preceded by lower case $p$. Conventional one-letter abbreviations: $A=$ alanine; $C=$ cysteine; $D=$ aspartic acid; $E=$ glutamic acid; $F=$ phenvlalanine; $G=$ glycine; $H=$ histidine; $I=$ isoleucine; $K=$ lysine; $L=$ leucine; $M=$ methionine; $N=$ asparagine; $P=$ proline; $Q=$ glutamine; $R=$ arginine: $S=$ serine; $T=$ threonine; $V=$ valine; $W=$ tryptophan; $Y=$ tyrosine.

problem with reversed-phase HPLC is the poor retention of small, highly polar peptides. For some phosphoproteins, a phosphorylated dipeptide or tripeptide would most likely elute in the flow-through and be obscured by coeluting buffer components.

IM $\Lambda$ C offers an altcrnative to LC mass spectrometry for complicated mixtures that contain phosphorylated peptides. Figure 4a shows the mass spectrum obtained from loading $10 \mathrm{pmol}$ of a $\beta$-casein tryptic digest onto the column and collecting data on the buffer $\mathrm{E}$ wash. Both the T1-2(4P) and T6(1P) peptides are observed in a narrow band, as shown in Figure 4a (inset). The intermediate $\mathrm{pH}$ washes were not necessary and were eliminated; however, the higher $\mathrm{pH}$ buffer $\mathrm{E}$ tends to degrade the column rapidly and leads to higher background signal. The peak eluting prior to the phosphopeptides is due to column degradation. On-line separation of the phosphopeptides was found to be crucial in this example. Attempts to collect low levels of the phosphopeptides off-line, concentrate them, and infuse them into the mass spectrometer always resulted in complete loss of the T1-2(4P) peptide. Adsorptive loss due to its hydrophobicity, as described above, is the probable cause. On-line methods reduce losses due to sample handling and are favored for low amounts of sample.

The $\beta$-casein example described above demonstrates adequate sensitivity for the technique. That work, however, was done with a 10-pmol aliquot from a large-scale tryptic digest $(5 \mathrm{nmol})$. Tryptic digestion of low-picomole levels of protein is much less efficient for several reasons. First, digestion in dilute solution proceeds much slower owing to slower reaction rales (rate is proportional to reactant concentrations). One must still maintain an enzyme-to-substrate ratio less than 10 to minirnize detection of trypsin autolysis fragments. Therefore, solution volumes must be kept as small as possible. The use of either immobilized enzyme or substrate can eliminate some of these problems [25, 29]. Second, a more serious problem that is frequently encountered with small amounts of material is the "state" of the solution in which the protein 


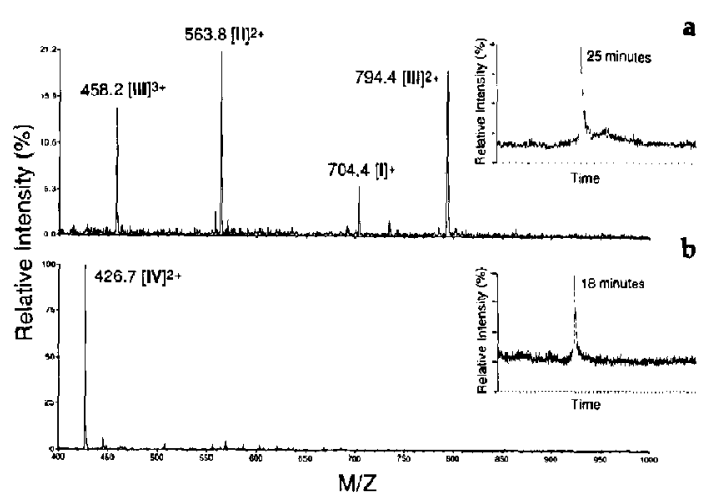

Figure 1. IMAC/ESI mass spectra of phosphopeptides. (a) 10 pmol each of phosphotyrosine peptides I, II, and III, buffer D wash. The number of charges on each ion is indicated. Inset: TIC trace of buffer D wash. (b) 20 pinol of phosphopeplide IV (kemptide), buffer D wash. Inset: TIC trace of buffer D wash.

is delivered. Frequently, the protein is dilute, not completely pure, and in a solution composition that may not be optimal for enzymatic digestion or subsequent analysis. There are numerous methods for concentration and/or buffer exchange of solutions, including dialysis, size exclusion chromatography, ultrafiltration, reversed-phase chromatography, and others. Each of these may work well for some proteins, but most result in adsorptive losses. Third, protein solubility is often low. Many proteins, particularly membranebound receptors, require detergent for solubility in aqueous solution. The detergent frequently interferes with enzyme activity and is normally incompatible with later mass spectral analysis. Maintaining adequate solubility without detergent can be difficult. Gel electrophoresis is frequently used as a final purification step prior to analytical work.

To minimize many of these problems, we used a method in which the protein is purified by SDS-PAGE, electroblotted onto a PVDF membrane, and digested in

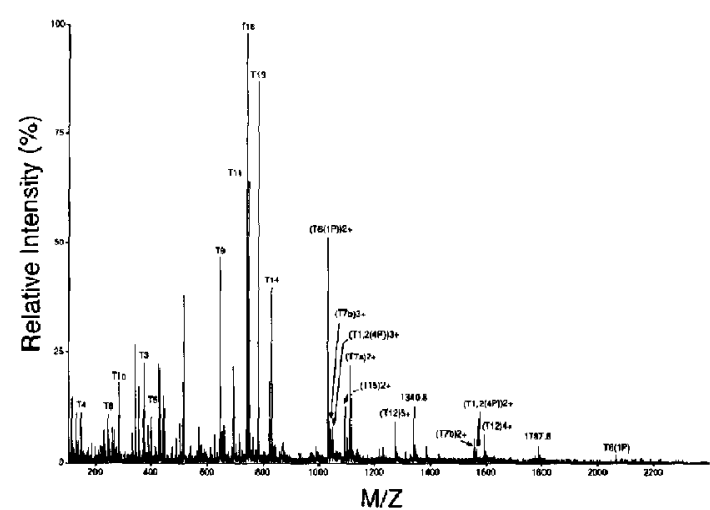

Figure 2. ESI mass spectrum of $4 \mu \mathrm{L}$ of a 5 -pmol $/ \mu \mathrm{L}$ solution of $\beta$-casein tryptic digest. The peptide mixture was infused directly. Ions are singly charged, except where indicated.

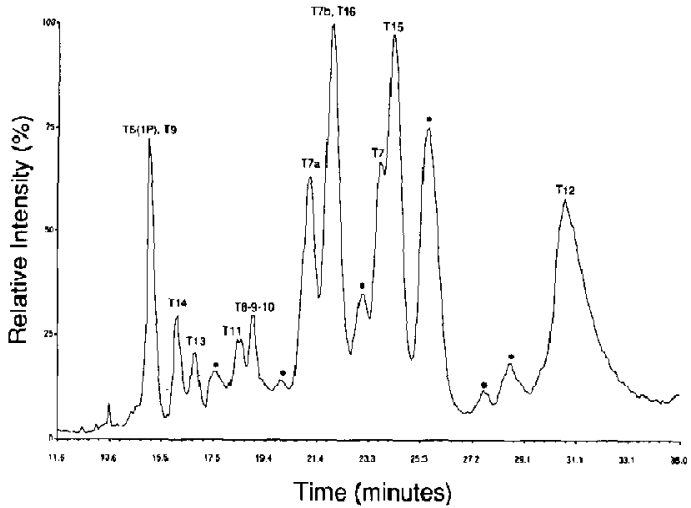

Figure 3. TIC trace of HPLC/ESI/MS of $60 \mathrm{pmol}$ of $\beta$-casein tryptic digest; ( $)$ nontryptic and modified peptides.

situ [23]. The resulting peptides are extracted from the membrane during the digestion process and the resulting solution directly analyzed. This method efficiently removes residual SDS, immobilizes the protein to a membrane for various enzymatic and chemical reactions (see Experimental), and minimizes sample handling. To demonstrate the success of this procedure, it was applied to $\beta$-casein. Although $\beta$-casein is not a large or insoluble protein, its use demonstrates the viability of the procedure because its digest mixture contains two peptides with very different degrees of phosphorylation as well as over a dozen other peptides covering a wide range of molecular weights and chemical nature. Figure 5 shows a PVDF membrane blotted with $30 \mathrm{pmol}$ of gel-purified $\beta$-casein. Following digestion, the peptides that were released from the PVDF membrane on hydrolysis were loaded onto an IM $\Lambda$ C column, washed, and eluted as described earlier. Figure $4 \mathrm{~b}$ shows the mass spectrum of the phosphopeptides that elute in a narrow band at high $\mathrm{pH}_{\text {, and the }}$

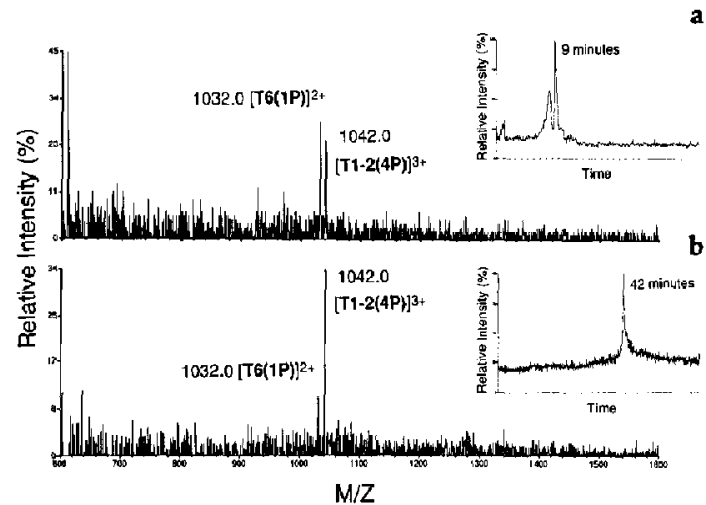

Figure 4. IMAC/ESI mass spectra of $\beta$-casein tryptic digest mixtures. (a) 10 pmol of digest, buffor $E$ wash. Inset: TIC trace of buffer $E$ wash. (b) $30 \mathrm{pmol}$ of $\beta$-casein digested in situ on a PVDF membrane, buffer D wash. Inset: TIC trace of buffer D wash. 


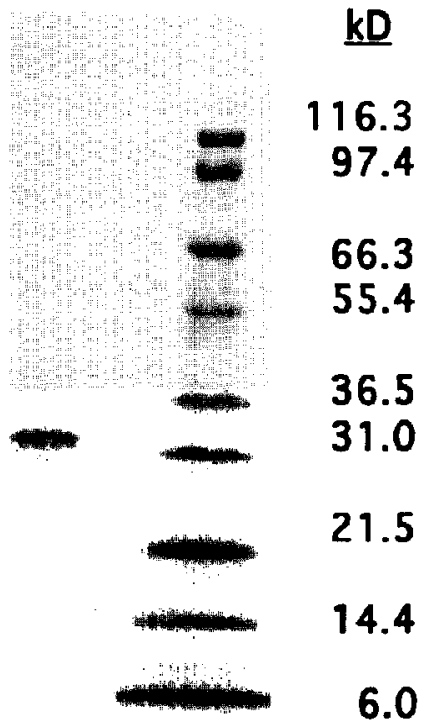

Figure 5. SDS-PAGE gel electroblotted onto a PVDF membrane and staincd with Coomassie blue: (left) 30-pmol $\beta$-casein; (right) molecular weight standards.

inset shows the TIC chromatogram. Ions from both phosphopeptides are observed.

Very recently, Yip and Hutchens [17] demonstrated the speed and sensitivity of MALDI/MS for the analysis of phosphopeptides derived from unfractionated tryptic digests of human $\beta$-casein. Our procedure (gel/blot/digest/IMAC) has also been used successfully to prepare samples for MALDI/MS. In our studies, the total amount of starting material was, as before, $30 \mathrm{pmol}$ of protein. Following the gel/blot/ digest/IMAC procedure, the eluted phosphopeptides of buvine $\beta$-casein were collected, dried, and redissolved in the matrix solution, as described above (see Experimental). The MALDI mass spectrum for peptides that elute with buffer $D$ is shown in Figure 6 . The molecular ions for both phosphopeptides are observed as well as small adduct ions for each molecular ion. The ion with $m / z 1032$ is most likely not the doubly charged T6(1P) peptide because no corresponding adduct ion is observed, and in our experience with this matrix mixture [27], no doubly charged ions are normally observed for peptides. Some loss in signal is observed for the quadruply phosphorylated peptide T1-2(4P) compared with the electrospray data. Most likely this is due to poor solubility in the acidic matrix solution as well as to losses incurred from drying the sample. The MALDI mass spectrum of an aliquot of the unfractionated $\beta$-casein solution tryptic digest, which was not dried prior to addition of matrix, shows nearly equal peak intensities for the two phosphopeptides [T6(1P) and T1-2(4P)], an indication that preferential ionization is not a factor.

Once the phosphopeptides are identified by mass, the precise location of the phosphate(s) within the

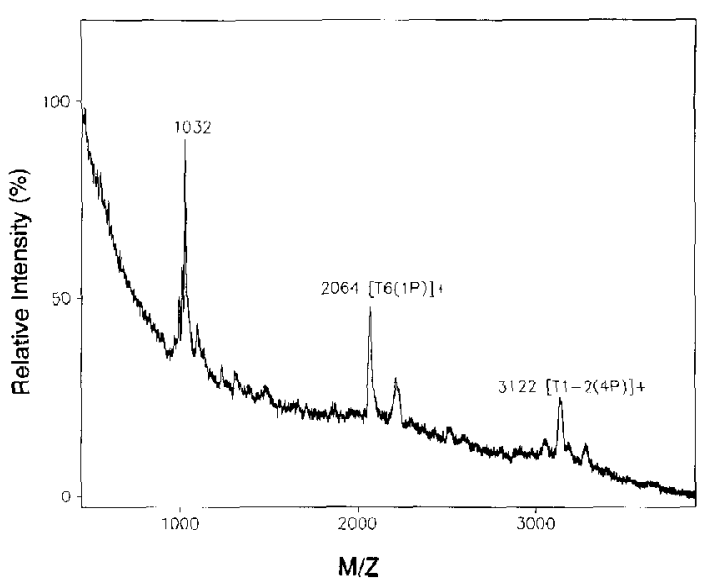

Figure 6. MALDI mass spectrum of $30 \mathrm{pmol}$ of $\beta$-casein digested in situ on a PVDF membrane. Off-line IMAC buffer D wash, dried and resolubilized in matrix (see Experimental).

peptide must still be determined. Tandem mass spectrometry in combination with ESI has the capability of providing sequences or partial sequences for many peptides [10, 11, 14, 16, 18]. A second experiment following the identification of the phosphopeptides, in which fragment ion spectra are acquired for each of the phosphopeptides, is then required.

Attempts to repeat this work with less than $30 \mathrm{pmol}$ of $\beta$-casein have so far been unsuccessful. Because the IMAC/ESI method has sufficient sensitivity to detect peptides at the 10-pmol level (Figures 1 and 4), the poorer detection limit for the gel/blot/digest procedure musl result from losses in these extra steps. Elcctroblotting efficiency can approach $100 \%$ for some proteins, but it may also be only $50 \%$ for other proteins, or less [33]. Blotting efficiency for $\beta$-casein on the basis of amino acid analysis following in situ hydrolysis of the blotted protein is approximately $50 \%$. The extraction process is also not quantitative. One might also expect inefficient digestion on the membrane, but experience with in situ tryptic digestion of many different proteins has shown partial digestion to be rare [33].

We expect that better detection limits can be achieved by further reduction in the size of the IMAC column [37]. Experiments with a packed capillary column $(0.4 \mathrm{~mm}$ i.d.) are currently in progress. Furthermore, a makeup solvent that reduces the $\mathrm{pH}$ may improve the ionization efficiency, because the $\mathrm{pH} 9.5$ or 10.5 solution presently used may not be optimal for generation of positively charged ions. This prediction is based on studies of positive ion generation for proteins at high $\mathrm{pH}$; the spectra show tenfold less signal than at low $\mathrm{pH}$ [34]. Along with changes in $\mathrm{pH}$, we are also investigating alternate elution buffers to reduce the abundance of background ions. In addition, in some instances, slight retention of more basic nonphosphorylated peptides has been observed (although not 
for other side-chain modifications such as sulfation), probably resulting from nonspecific interactions with free iminodiacetic acid. Elution buffers containing $\mathrm{Mg}^{2+}$, imidazole, or phosphoserine have been shown to eliminate some of these interactions $[25,35,36]$. With proper optimization of column and solvent conditions, flow rate, and mass spectral scan conditions, it is possible that some degree of chromatographic resolution could be achieved for mixtures of phosphopeptides $[19,20,22]$. In addition, further separation by using reversed-phase HPLC could be used following the IMAC. These improvements are in progress. This procedure is presently being applied to the determination of the phosphorylation sites of a $120-\mathrm{kDa}$ membrane-bound receptor.

\section{Acknowledgments}

The authors thank Bill Henzel and Suzy Wong for their assistance with the in situ tryptic digestion procedure. Amino acid analysis was provided by Allan Padua.

\section{References}

1. Rosen, O. M.; Krebs, E. G., Eds. Protein Phosphorylation, Books $A$ and $B$; Cold Spring Harbor Conferences on Cell Proliferation, Vol. 8.; Cold Spring Harbor Laboratory: Cold Spring Harbor, NY, 1981.

2. Hunter, T.; Sefton, B. M., Eds. Methods in Enzymology, Vol. 200 and 201; Academic: San Diego, 1991.

3. Kemp, B.E., Ed. Peptides and Protein Phosphorylation; CRC: Boca Raton, FL, 1990.

4. Martensen, T. M. In: Methods in Enzymology; Vol. 107, Wold, F,; Moldave, K., Eds.; Academic: San Diego, 1984; $\mathbf{p} 3$.

5. Engstrom, L.; Ekman, P.; Humble, E.; Ragnarsson, U.; Letterqvist, $O$. In Methods in Enzymology; Vol. 107, Wold, F.; Moldave, K., Ed.; Academic: San Diego, 1984; p 130.

6. Annan, W. D; Manson, W.; Nimmo, J. A. Anal. Biochem. 1982, 121, 62-68.

7. Meyer, H. E.; Hoffmann-Posorske, E; Korte, H.; Heilmeyer, L. M. G. Jr. FEBS Lett. 1986, 204, 61-66.

8. Meyer, H. E.; Hoffmanu-Posorske, E.; Korte, H.; DonellaDeana, A.; Brunati, A.-M.; Pinna, L.A.; Coull, J.; Perich, J.; Valerio, R.M: Johns, R.B. Chromatographia 1990, 30, 691-695.

9. Craig, A. G.; Engstrom, A.; Bennich, H.; Hoffmann-Posorske, E.; Meyer, H. E. Biol. Mass Spectrom. 1991, 20, 565-574.

10. Gibson, B. W.; Cohen, P. In: Methods in Enzymology; Vol. 193, McCloskey, J. A., Ed; Academic: San Diego, 1990; p 480.
11. Gibson, B. W.; Falick, A. M.; Burlingame, A. L.; Nadasdi, L.; Nguyen, A. C.; Kenyon, G. L. J. Am. Chem. Soc. 1987, 109, 5343-5348.

12. Fenselau, C.; Heller, D. N.; Miller, M. S.; White, H. B. III. Anal. Biochem. 1985, 150, 309-314.

13. Jones, D. S.; Heerma, W.; van Wassenaar, P. D.; Haverkamp, J. Rapid Commun. Mass Spectrom. 1991, 4, 192-95.

14. Michel, H; Hunt, D. F.; Shabanowitz, J.; Bennett, J. J. Biol. Chem. 1988, 263, 1123-1130.

15. Casetta, B.; Bonner, R.; Shushan, B.; Fior, G. Org. Mass Spectrom. 1992, 27, 211-214.

16. Covey, T.; Shushan, B.; Bonner, R. In: Methods in Protein Sequence Analysis; Jornvall, H.; Hoog, J.-O.; Gustavsson, A.-M, Eds.; Birkhauser Verlag: Basel, 1991; p 249.

17. Yip, T-T.; Hutchens, W. FEBS Lett. 1992, 308, 149-153.

18. Palczewski, K.; Buczykko, J.; Van Hooser, P.; Carr, S. A.; Huddleston, M. J.; Crabb, J. W. J. Biol. Chem. 1992, 267, 18991-18998.

19. Andersson, L.; Porath, J. Anal. Biochem. 1986, 154, 250-254.

20. Muszynska, G,; Andersson, L.; Porath, J. Biochem. 1986, 25, $6850-6853$.

21. Michel, H.P.; Bennett, J. FEBS Lett. 1987, 212, 103-108.

22. Scanff, P.; Yvon, M.; Pelissier, J. P. J. Chromatogr. 1991, 539, 425-432.

23. Wong, S. C.; Grimley, C.; Padua, A.; Bourell, J. H.; Henzel, W. J. In: Techniques in Protein Chemistry IV; Angeletti, R. H, Ed., Academic Press: San Diego, 1993; pp. 371-378.

24. Henzel, W. J.; Billeci, T. M.; Stults, J. T.; Wong, S. C.; Grimley, C.; Watanabe, C., Proc. Natl. Acad. Sci. USA 1993, in press.

25. Chicz, R. M.; Regnier, F. E. In: Methods in Enzymology; Vol. 182, Deutscher, M. P., Ed.; Academic: San Diego, 1990; p 392.

26. Koster, C.; Castoro, J.; Wilkins, C. L. J. Am. Chem. Soc. 1992, $114,7572-7574$.

27. Billeci, T. M.; Stults, J. T. Anal. Chem. 1993, in press.

28. Leadbeater, L; Ward, F. B. J. Chromatogr. 1987, 397, 435-443.

29. Lemieux, L.; Amiot, J. J. Chromatogr. 1990, 519, $299-321$.

30. Chaplin, I. C.; Andrews, A. T. J. Chromatogr. 1988, 450, 420-425.

31. Pucci, P.; Sepe, C. Biomed. Environ. Mass Spectrom. 1988, 17, $287-291$.

32. Jones, D.; Kimber, M.; Moore, C. Proceedings of the 40th ASMS Conference on Mass Spectrometry and Allied Topics; Washington, DC, May 31-June 5, 1992.

33. Fernandez, J.; DeMott, M.; Atherton, D.; Mische, S. M. Anal. Biochem. 1992, 201, 255-264.

34. Kelly, M. A; Vestling, M. M.; Fenselatu, C. C.; Smith, P. B. Org. Mass Spectrom. 1992, 27, 1143-1147.

35. Nakagawa, Y.; Yip T.-T.; Belew, M.; Porath J. Anal. Biochem. $1988,168,75-81$.

36. Sulkowski, E. Trends Biotechnol. 1985, 3, 1-7.

37. Flurer, C. L.; Novotny, M. I. Microcol. Sep. 1992, 4, 497-501. 